UDC: $159.922 .8+[159.922 .27-053.6: 316.6]$

DOI: https://doi.org/10.24195/2414-4665-2017-7-14

Anzhelika Shamne,

Doctor of Psychology, associate professor, Department of Social Work and Psychology, National University of Life and Environmental Sciences of Ukraine, 10, Heroyiv Oborony St., Kyiv, Ukraine

\title{
VARIABLE-TYPOLOGY MAPPING OF PSYCHOSOCIAL DEVELOPMENT IN ADOLESCENCE
}

The paper, based on the methodology of the factor and variable patterns analyses, deals with a typological map of individual forms of development in adolescence. Personal (motivation, value orientations, communicative options), subjective (autonomy, self-regulation, locus of control) and social behavioral (styles, forms, strategies of functionality and social activity) characteristics of teenagers are used as the criteria of typification. The sample was formed by university students $(N=460,34 \%$ males). Four types of the psychosocial development were identified (harmonious, subjectively-dominant, depending adaptive and disintegrated). The constructive development in adolescence is represented by the "harmonious" type. It has the following characteristics: a balance between the individual and the social in the structure of development, productive solving of age-specific problems and efficiency of functioning (psychosocial integration). The non-constructive (unproductive) model is represented by the types focusing on the hyper-social ("depending adaptive" type) or hypo-social ("subjectively-dominant type") mindsets. The representatives of the depending adaptive type are dependent on other people and circumstances, and the adolescents of the subjectively-dominant type can be marked by the reduced social interest and desire to dominate.

Keywords: psychological social development, the type of development, adolescence, individualization, personality, typification criteria, prevention.

\section{Introduction}

Establishing the general patterns of ontogeny has always been the main objective of the developmental psychology. In practical activities, psychologists do not, however, deal with the regulatory development as such, but with its specific and individualized forms. The relevance of the variable-typology aspect research of the age-specific development is therefore conditioned, above all, by the most urgent needs of the psychological practice.

The issue of correlation between age-specific and individual features, combining typological and dynamic approaches are represented in the research studies by K. Abulkhanova-Slavska [1], H. Burmenska [2], J. Loevinger [6] and others. Their general idea is to try and combine two aspects of ontogeny, i.e. age-specific/genetic (developmental psychology) and differential-psychological (differential psychology) ones. H. Burmenska suggested creating a special branch of developmental psychology called "differential developmental psychology", which would reflect the variability of individual development forms [2].

In western psychology, those ideas, in the form of the variable patterns approach, were represented in the papers by P. B. Baltes (1983) [5], L. R. Bergman (1996), D. Magnusson (1996) [7]. D. Magnusson stresses that during the process of development the personal becoming occurs. "...Every step of the development leads ... to shaping of more distinct 'types' than in the early stages... Based on the similarity of patterns, individuals can be combined into groups or subgroups" [7]. P. Baltes [5] emphasizes that the development process has great flexibility and variability that determine the potential for the implementation of various forms of behavior and development in ontogeny.

Since adolescence, the variability of ways of the development is associated with the fact that, on the one hand, human life involves various ratios of individual and social determinants of development; on the other hand, it involves various ratios of determination and selfdetermination $[1 ; 4]$. We therefore posited the ratio of the following indicators: personality-specific and communicative properties - distribution of young people by the individual mental content (needs, motivation, value orientations, focus, attitude to oneself and other people, individualism-collectivism, system of value orientations, etc.); subject-specific characteristics - their distribution by the level and type of activity (self-regulation, locus of control, adaptability/extra-situational attitude, external/internal determination, etc.); characteristics of social functioning (styles of interaction; distinctive features of communication and attitude towards people, those of behavior in a conflict; types of coping strategies, etc.); the presence and the level of manifestation of the crisis of personality and that of an individual person.

Previous studies based on those criteria have empirically identified four types of the development in adolescence (12-16 years) ("autonomously self-sufficient", "internally dominant", "friendly dependent" and "frustrated/crisis-stricken") [3].

The paper aims to determine a variable-typology mapping of the development in adolescence (as exempli- 
fied by university students). The aim involves addressing the following tasks: 1) explore the typological map of the development of modern young people; 2) define the phenomenological map of each type of the development; 3) substantiate the problem areas of development that need correction.

\section{Research Methods}

The study involved 460 university students of the $1^{\text {st }}$ $3^{\text {rd }}$ years of study (17-22 years) from the cities of Kryvyi Rih and Kyiv. A set of valid diagnostic techniques was used: the Biographical Questionnaire; 16PF Questionnaire by R. Cattell (the A, H, E, Q $2, \mathrm{~N}$ and L scales); Personal Orientation Questionnaire by V. Smekal and M. Kucher (POQ); Semantic Differential Scale (SD) (an adapted version in the St. Petersburg Psychoneurological Research Institute named after V.M. Bekhterev); The Test Anxiety Scale for Children (by B. N. Phillips); the Self-Attitude Scale by V. Stolin; the author's testquestionnaire "Psychosocial Development of Adolescents" (PDA) and "Crisis of Adolescence" (factors: crisis of relations, crisis of activity) [3]; Sense-of-life Orientation Test (SLO) by D. Leontyev; Level of Subjective Control Test (LSC) by E. F. Bazhin, E. A. Golynkina and A.M.Etkind;The Personal Orientation Inventory (POI); the Thomas-Kilmann Conflict Mode Instrument (TKI); Diagnostics of Interpersonal Relations (DIR) by T. Leary (Octants I-VIII); Individualism-Collectivism Indicators by L. G. Pochebut; Coping Strategy Indicator (CSI) by J. Amirkhan; The Coping Inventory for Stressful Situations (S. Norman, D. Endler, D. James, M. Parker, the adapted version by T. Kryukova); Sociometric method.

\section{Discussion}

We proceeded from the provision on data factorization as a way to implement the pattern approach, so the statistical processing of the diagnostics results was carried out using the factor analysis. The four-factor model which explains $49.96 \%$ of the data variance in the sample studied (Table 1), has major substantive and statistical advantages (maximum resilience, high contrast value and information reliability).

The first factor (which explains $19.523 \%$ of the data variance, at $\mathrm{p}<0.01$ ) was interpreted as "harmonious" type (pattern) of the development. The representatives of this type are characterized by an independently dominant behavioral style, internality in family relationships, distrustfully skeptical type of interpersonal relationships, positive attitude towards people, focus on interaction, flexibility, sociability, spontaneity. Among the personality traits, there are confidence, ego strength, positive self-attitude, the ability to achieve goals and the absence of anxiety. Among social traits, there is a favorable family atmosphere.

These young people have internal locus of control, positive ego-identity, a high level of subjective wellbeing, clear goals in life; they are positive about themselves, their past, present and future, they are happy with themselves and have congruent relations with the social environment (sociability, lack of suspicion, positive atti- tude towards people and focus on interaction). The principal meaning of the development of the representatives of this type is self-actualization, integration into the social environment and purposeful life activity.

The profile of the second factor was interpreted as the "subjectively-dominant" type of development. Its representatives are characterized by high values on the dominance, internality and subject-activity scales. Among the personality characteristics, "strong" styles of behavior in conflicts predominate: the competition and avoidance scales, "strong" styles of interpersonal relationships, focus on oneself (individualism), independence on other people, focus on material achievements, social activity, sociability, desire to control; lack of compassion, sensitivity, emotional attitude towards people, sometimes harshness and selfishness; low affiliation and low focus on the opinions of others. At the same time, they can be also described by focus on business, internality in all areas of life (in the areas of achievements, failures, interpersonal and family relationships), autonomy and active strategies of coping behavior (problem solving). This type shows the focus on oneself (individualism), the desire to control the environment and succeed. The main features of the development of the representatives of this type are selfrealization, the desire for superiority over others, focus on business and dominance in relationships.

The third factor represents the "depending adaptive" type. Octants VII the technique of T. Leary "Diagnostics of interpersonal relations" (DIR) "Goodwill" (focus on social acceptance, commitment to goals of a micro-group; propensity for cooperation, compromise; striving to earn recognition and love) and VIII "Altruistic" (responsibility towards people, sensitivity, kindness, desire to render assistance; capacity for compassion, caring; flexibility in contacts, readiness for self-sacrifice) have the greatest weight. At the same time, Octant VI "Dependent" indicates insecurity, increased personal anxiety, dependency on other people's opinions, obedience, timidity, conformity, credulity.

Representatives of this type are characterized by such a behavior style in conflict situations as adaptability and readiness for compromise, affability, openness, dependency on a group, flexibility in communication, pronounced "external ego" (lack of self-sufficiency, dependency on other people's opinions and demands, high sociability, sensitivity to social approval), willingness to cooperate, consideration for people. This is a type of young people oriented at group activities. The inverse values of the "personality crisis" indicator confirm a high level of involvement in the relationships.

Representatives of this type are oriented primarily at the demands of the social environment, the opinion and position of others, observance of social standards at the expense of self-realization. This is corroborated by the low scores on "Self-understanding" and "Autonomy" scales (The Personal Orientation Inventory), which indicate the complication of the development of this youth as the "authors" (subjects) of life. 
The content of factors or patterns of psychosocial development in adolescence

\begin{tabular}{|c|c|c|}
\hline Name & Basic components of factorb and their weight & Weight \\
\hline $\begin{array}{l}\text { Harmonious } \\
\text { (integrated) }\end{array}$ & $\begin{array}{l}\text { Negative ego-identity }(-0.806) \text {, the result of living }(0.801) \text {, internal locus of control-ego }(0.762), \\
\text { goals in life }(0.754) \text {, externality }(-0.736) \text {, subjective well-being }(0.681) \text {, locus of life }(0.636), \\
\text { Self power }(-0.623) \text {, sociability }(0.534) \text {, spontaneity }(0.496) \text {, material values }(-0.490) \text {, Educa- } \\
\text { tion (style) }(-0.489) \text {, Octant II }(0.437) \text {, flexibility }(0.431) \text {, Octant IV }(-0.409) \text {, Internality in } \\
\text { Family Relations }(0.410) \text {, focus on the interaction }(0.410) \text {, general anxiety }(-0.399)\end{array}$ & 19.5 \\
\hline $\begin{array}{l}\text { Subjectively- } \\
\text { dominant }\end{array}$ & $\begin{array}{l}\text { Competition }(0.709), \quad \text { Octant } \text { I }(0.693), \quad \text { avoidance }(-0.669), \\
\text { Octant III }(0.642) \text {, autonomy }(0.636) \text {, internality in achievements }(0.575) \text {, Internality in Relation } \\
\text { to Health and disease }(0.569) \text {, Internality in Interpersonal relationships }(0.529) \text {, Social activity } \\
(-0.508) \text {, Octant II }(0.508) \text {, material values }(0.454) \text {, Internality in Family Relations (0.443), } \\
\text { subject crisis (-0.433), focus on business }(0.431) \text {, Internality in Failure }(0.426) \text {, individualism } \\
(0.416) \text {, problem solving - coping }(0.403)\end{array}$ & 16.56 \\
\hline $\begin{array}{l}\text { Depending } \\
\text { adaptive }\end{array}$ & $\begin{array}{l}\text { Octant VII }(0.903) \text {, self-understanding }(-0.807) \text {, adaptation }(0.707) \text {, Octant VIII }(0.618) \text {, socia- } \\
\text { bility }(0.566) \text {, personality crisis }(-0.470) \text {, conformism }(-0.469) \text {, flexibility }(0.450) \text {, autonomy }(- \\
0.445) \text {, compromise }(0.398) \text {, Octant VI }(0.448) \text {, Octant II }(-0.420) \text {, sociability }(0.413) \text {, collectiv- } \\
\text { ism }(0.400) \text {, formal criterion according to sociometry }(-0.390)\end{array}$ & 12.23 \\
\hline $\begin{array}{l}\text { Disintegrated } \\
\text { (negative } \\
\text { identity) }\end{array}$ & $\begin{array}{l}\text { Octant VI }(0.733) \text {, sociability }(0.701) \text {, values }(-0.698) \text {, Octant V }(0.570) \text {, negative ego-identity } \\
(0.534) \text { view of human nature }(-0.514) \text {, focus on the interaction }(-0.471) \text {, creativity }(-0.457), \\
\text { Social activity }(0.454) \text {, spontaneity }(-0.441) \text {, subjective well-being }(-0.441) \text {, crisis of the indi- } \\
\text { vidual }(0.433) \text {, self-sympathy }(-0.430) \text {, orientation in time }(-0.427), S(-0.417) \text {, general anxiety } \\
(0.417) \text {, Social status }(0.390) \text {, crisis of the personality }(0.39)\end{array}$ & \\
\hline
\end{tabular}

The fourth factor (the factor weight is $9.681 \%$ ) represents the "disintegrated" type of development. Its representatives have problems with solving the fundamental dichotomies (problems) of psychosocial development:

1) problems with the autonomous behavior and the formation of the subject of life. This is borne out by the external locus of life characteristic of this type, social passiveness, negative idea of oneself in the past, the present and the future, dissatisfaction with oneself and one's life, fatalism, negative attitude to the values of selfactualization, impersonal locus of causality, neuroticism, recurrence to past experiences, increased desire to pursue one's objectives, uncertainty;

2) problems with the attitude towards people. This is borne out by the negative view of human nature, ill will, negative attitude to people (POI), inverse values of the "Focus on the interaction" scale (Personal Orientation Questionnaire by V. Smekal - M. Kucher), problems in communication, inability to maintain social contacts, problems in self-realization, low social activity and communication skills. At the same time, this type is characterized by negative self-attitude and a low value of "Selfsympathy" according to POI;

3) psychosocial adaptation problems, which are manifested in insecurity, increased personal anxiety, pronounced affiliation demands, dependence on the opinions and demands of others, unhealthy sensitivity to social approval, tendency to self-abasement, self-accusation.

The outlined problems of personality's development explain the emergence of the systemic psychosocial crisis of adolescence. It is manifested in expressed stress in personal and social situations, social adaptation difficul- ties, negative self-attitude; high level of anxiety, frustration, neuroticism. It should be noted that this systemic crisis has little to do with the family situation and the external circumstances of development as a whole. The phenomena of maladjustment are caused by unresolved problems of age, passive and dependent "I-am-amongthe-people" attitude, internal and external problems (social maladjustment; impersonal, external causality; dissatisfaction with life; rejection of self-actualization, which results in the loss of one's ego; neurotic symptoms of accommodating type, etc.). In extreme cases, a young person of this type of regulation turns out to be almost entirely dependent on external circumstances, groups, as well as his/her own inhibitions and neurotic emotions.

\section{Conclusions}

The application of the methodology of the variable patterns and factor analyses, as well as various criteria of development typification (personality, subject, social and behavioral characteristics) to the empirical data obtained made it possible to outline a typological mapping of individual forms of the development in adolescence. Four types of the psychosocial development have been identified (harmonious, subjectively-dominant, depending adaptive and disintegrated). In the context of the ideas of J. Loevinger's integrative concept [6], we can say that those patterns of the development become personality types, which in turn leads to further scenario (option) of the development "chosen" by the individual. The types identified are also the levels of the psychosocial development. They can be differentiated by the parameters of constructiveness (optimal solution of development problems), non-constructiveness (one-sided focus on oneself 
or others) and destructiveness (imbalance, disintegration, systemic crisis).

The constructive development in adolescence is represented by the "harmonious" type. Its main features are as follows: a balance between the individual and the social in the structure of development, productive solving of age-specific problems and efficiency of functioning (psychosocial integration).

The non-constructive (unproductive) model is represented by the types focusing on the hyper-social ("depending adaptive" type) or hypo-social ("subject dominant type") mindsets. The first types are characterized by tendencies of formation of a conformist, non-selfsufficient individual who is dependent on other people and circumstances, the second ones are marked by reduced social interest and desire to dominate. The excessive roles of dependent (infantile) or individualistic strategies, prevailing conformism (the search for social support) or dominance (the desire of superiority) are of pseudo-compensatory character. In both cases, that leads to the reduction of the self-actualization potential.

The "disintegrated" type demonstrates a destructive development model and, consequently, the most unfavorable path of psychosocial development. Its repre-

\section{REFERENCES}

1. Abulkhanova-Slavskaya, K.A. (1983). O putyah postroeniya tipologii lichnosti [On ways the construction of a typology of personality]. Psihologicheskiy zhurnal Psychological journal, 1 (4), 14-29 [in Russian].

2. Burmenskaya, G.V. (2000) Tipologicheskiy podkhod $\mathrm{V}$ vozrastnoy psikhologii razvitiya [The typological approach in psychology of development]. Vestnik MGU - Bulletin of MSU. Seriya 14 - Series 14, 4, 3-19 [in Russian].

3. Shamne, A.V. (2015) Teoriya ta praktika psihosotsialnoho rozvitku u pidlitkovo-yunatskomu vitsi [Theory and practice of psychosocial personality development in adolescent]. Kyiv: Interservis [in Ukrainian].

\section{ЛІТЕРАТУРА}

1. Абульханова-Славская К. А. О путях построения типологии личности / К. А. АбульхановаСлавская // Психологический журнал.- №1(4) - 1983 C. $14-29$.

2. Бурменская Г. В. Типологический подход в возрастной психологии развития / Г. В. Бурменская // Вестник МГУ. Серия 14. - 2000. - № 4. - С. 3-19

3. Шамне А. В. Теорія та практика психосоціального розвитку у підлітково-юнацькому віці / А. В. Шамне. - Київ : ТОВ ВНП «Інтерсервіс», 2015. $488 \mathrm{c}$.

4. Shamne A. V. The conceptual model of psychosocial development in the period of adolescence / sentatives have a low level of almost all self-actualization indicators, they are oriented "against people", highly frustrated and crisis-inclined, have external locus of control, are dissatisfied with themselves and life, have negative ego-identity, impersonal locus of causality and a low level of autonomy. They are dependent on external circumstances, groups, their own inhibitions and neurotic emotions.

The variety of individual development options must orient the diagnostic testing strategy and prompt vectors of conditionally variable forecasting, which always appears as an array of possible ways for further development of an individual. The presence of problem areas and development deformations for representatives of the "subjectively-dominant", "depending adaptive" and "disintegrated" types requires targeted and systematic psychoprophylaxis in the unity of its three levels, i. e. primary, secondary and tertiary ones, with both age-specific and individual characteristics of young people taken into account. The results of the research make it possible to build psychological support, forecast and correct unproductive ways and crisis manifestations of the development in adolescence.

4. Shamne, A.V. (2013) The conceptual model of psychosocial development in the period of adolescence. Science and Education a New Dimension. Pedagogy and Psychology, 3, 165-169 [in English].

5. Baltes, P.B. (1983) Lif-span developmental psychology: Observations on history theory revisited. N. J.: Erlbaum [in English]

6. Loevinger, J. (1976) Ego development: Conceptions and theories. San Fracisco: Jossey-Bass [in English].

7. Magnusson, D. (1996) The logic and implications of a person approach. Reports from the Department of Psychology Stockholm Univ, 817, 1004-1034.

A. V. Shamne // Science and Education a New Dimension. Pedagogy and Psychology. - 2013. - Vol. 3. P.165-169.

5. Baltes, P. B. Lif-span developmental psychology: Observations on history theory revisited / P. B. Baltes. N. J.: Erlbaum, 1983. - 176 c.

6. Loevinger J. Ego development: Conceptions and theories / J. Loevinger. - San Fracisco: Jossey-Bass, 1976. $-399 \mathrm{p}$.

7. Magnusson D. The logic and implications of a person approach / D. Magnusson // Reports from the Department of Psychology Stockholm Univ. -1996. - N. 817. - P. 1004-1034. 


\section{Анжеліка Володимирівна Шамне, \\ доктор психологічних наук, доцент, професор кафедри соиіальної роботи та психології, Національний університет біоресурсів та природокористування Украӥни, вул. Героїв оборони, 10, м. Київ, Україна}

\section{ВАРІАТИВНО-ТИПОЛОГІЧНА КАРТИНА \\ ПСИХОСОЦІАЛЬНОГО РОЗВИТКУ В ЮНАЦЬКОМУ ВІЦІ}

Проблема співвідношення вікових та індивідуальних закономірностей розвитку залишається однією з найбільш практично значущих i, водночас, - найменш емпірично досліджених у сучасній психології. Шляхи іiі розв'язання концентруються на спробах поєднання двох аспектів онтогенезу - віково-генетичного (психологія розвитку) і диференційно-психологічного (диференційна психологія). В основу дослідження покладено ідеї типологічного (варіативно-паттернового підходу) підходу до розвитку особистості (П. Балтес, Г. Бурменська, Дж. Ловінгер, Д. Магнуссон та ін.). У статті представлено результати теоретичного та емпіричного дослідження варіативно-типологічних форм нормативного розвитку особистості. У якості критеріїв типізації було використано особистісні (мотивація, ціннісні орієнтації, спрямованість, комунікативні властивості), суб'єктні (автономність, саморегуляція, локус контролю) і соціально-поведінкові (стилі, форми, стратегії соціального функціонування і соціальної активності) характеристики. Вибірку склали 460 студентів 1-3 курсів (17-22 pp.) ВН3 (34\% чоловічої статі). В основу інтерпретації результатів було покладено положення про факторизацію даних як шлях реалізації паттернового підходу. Статистична обробка результатів діагностики здійснювалася із застосуванням факторного аналізу. Змістові і статистичні переваги мала чотирьохфакторна модель (49,96\% дисперсії даних). На основі методології факторного і варіативнопаттернового аналізу окреслено типологічну картину індивідуальних форм розвитку у юнацькому віці. Визначено чотири типи (паттерни) психосоціального розвитку («гармонійний», «суб’єктно-домінантний», «залежноадаптивний», «дезінтегрований»), описано їх психологічні особливості, феноменологічну картину та проблемні зони, які потребують корекції. Для представників «гармонійного» типу основним змістом розвитку є самоактуалізація, інтегрованість у соціум, цілеспрямована життєва активність; для «суб’єкно-домінантного» - самореалізація, прагнення до переваги над іншими, спрямованість на справу, домінантність у стосунках; для «залежноадаптивного» - орієнтація на пристосування до інших (групи), залежність, спрямованість на взаємодію; для «дезінтегрованого» типу - дезадаптивність, проблеми з автономною поведінкою, спрямованість «проти людей», психосоціальна криза. Виявлено типи диференційовано за параметром конструктивності (тип «гармонійний»), неконструктивності (типи «суб’єктно-домінантний», «залежно-адаптивний») і деструктивності (тип «дезінтегрований»). Останній демонструє найбільш несприятливий варіант психосоціального розвитку (залежність від зовнішніх обставин, групи, власних комплексів та невротичних переживань). Наявність проблемних зон і деформацій розвитку особистості у представників «суб'єктно-домінантного», «залежно-адаптивного» і особливо «дезінтегрованого» типів потребує цілеспрямованої психопрофілактики (корекції) з урахуванням як вікових, так і індивідуальних особливостей молоді.

Ключові слова: психосоціальний розвиток, тип розвитку, юнацький вік, індивідуалізація, особистість, критерії типізації, профілактика.

Submitted on June, 14, 2017 